\title{
Nature ダイジェスト trích đăng bài ISR
}

\author{
Nguyễn Minh Hoàng \\ Trung tâm ISR \\ Trường ĐH Phenikaa \\ Ngày 9 tháng 11 năm 2020
}

http://isr.phenikaa-uni.edu.vn/chitiet/tin-tuc_2019_2_22_7_58_84/nature--trich-dang-bai-

isr

Trong volume 17 của Nature ダイジェスト trích đăng bài của tác giả Vương Quân Hoàng, Trung tâm ISR, Trường ĐH Phenikaa. (Xem ảnh chụp màn hình trang web của bài báo phía dưới.)

Có thể tham khảo bài báo nói trên tại địa chỉ URL: https://www.natureasia.com/jajp/ndigest/v17/n8/論文撤回を改革して透明性を高めょ/104106

論文撤回を改革して透明性を高めよ口

Nature ダイジェスト Vol. 17 No. 8 | doi : 10.1038/ndigest.2020.200818
原文 : Nature (2020-06-08) | doil: 10.1038/d41586-020-01694-x | EN Reform retractions to make them more
transparent圆
Quan-Hoang Vuong
科学コミュニティーは、学術誌などに揭载された論文を撤回する際、提供すべき必須の情報について合意
する必要がある。

2020年6月、The New England Journal of Medicine と Lancetは、COVID-19の治療法について試験した、異論の 多い研究についての詥文を撤回した。両誌共、公衆からの 批判が果たした役割には言及していない。今回のCOVID19パンデミックに関連する論文やプレプリントに関して は、これらの他にも撤回されたものがいくつもあり、その 多くは理由を十分に説明していない。ブログ「Retraction Watch」は、COVID-19関連㻅文の撤回について集計を始 めている。

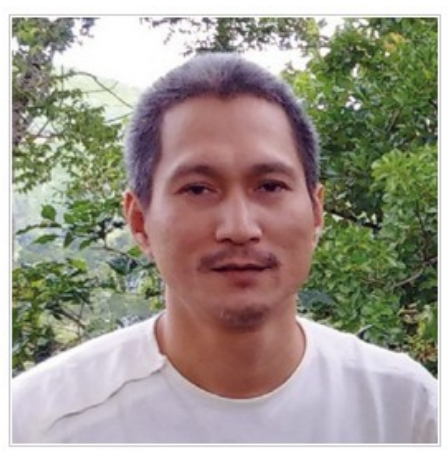

QUAN-HOANG VUONG |
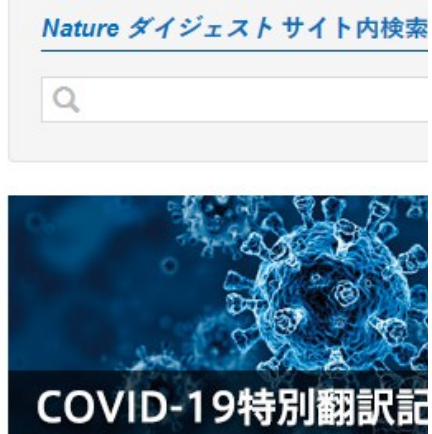

メメーマガジン登録

口 サイトライセンス

Nature Japanとつながろう

①

カテゴリー娭索

Nature ダイジェスト; doi : 10.1038/ndigest.2020.200818 [1] 
Kể từ khi bài gốc tiếng Anh được đăng trên Nature vol. 582, iss. 7811 [2], đã có các phiên bản trích lược và đầy đủ được đăng bằng các ngôn ngữ chủ chốt như Tây Ban Nha [3], Trung Quốc [4], Đức [5], Nhật [1].

\section{References:}

[1] Quan-Hoang Vuong. (2020). 論文撤回を改革して透明性を高めょ. Nature ダイジェ スト, 17( 8), doi : 10.1038/ndigest.2020.200818.

[2] Quan-Hoang Vuong. (2020). Reform retractions to make them more transparent. Nature, 582(7811), 149.

[3] Quan-Hoang Vuong. (2020). ¿Cómo retractarse en ciencia?. Investigación y Ciencia, $\mathrm{N}^{\circ} 530$ (Noviembre 2020). URL:

https://www.investigacionyciencia.es/revistas/investigacion-y-ciencia/grandeshitos-y-prximos-retos-de-la-ciencia-811/cmo-retractarse-en-ciencia-19145

[4] 李晨阳, and 徐竞然 (2020). 要撤稿? 请交代清楚这 4 点！中国科学报社 (9 June). http://news.sciencenet.cn/htmlnews/2020/6/441196.shtm

[5] Michael Springer (2020). Selbstkontrolle mit kleinen Fehlern. Spektrum der Wissenschaft (26 Oct.). *URL: https://www.spektrum.de/kolumne/luecken-impeer-review-prozess/1771644 